\title{
Effect of Integrated Nutrients Management with Plant Growth Retardant on Flower Quality and Economics of African Marigold (Tagetes erecta L.) cv. Pusa Narangi Gainda
}

\author{
Yatendra Kumar*, Vishwanath and P. K. Upadhyay \\ Department of Horticulture, Kulbhaskar Ashram P.G. College, \\ Prayagraj (U.P.) -211001, India \\ *Corresponding author
}

Keywords

Biofertilizers, Azotobacter, African marigold, Tagetest erecta L., Integrated Nutrients Management, PGR, Vermicompost, Cycocel

\section{Article Info}

Accepted:

08 January 2020

Available Online:

10 February 2020

\section{A B S T R A C T}

The present investigation was conducted at Horticulture Research Farm, Department of Horticulture, Kulbhaskar Ashram P.G. College, Prayagraj, U.P. during the year 2016-2017 and 2017-18. The experiment was laid out in Randomized Block Design with three replications consisted of 36 treatments with control. The four levels of Azotobacter, three levels of PSB and three levels of Vermicompost with fixed dose of cycocel along with control was taken. The results revealed that application of the treatment $T_{22}$ (Azotobacter- $500 \mathrm{ml} / \mathrm{ha}$, PSB- $500 \mathrm{ml} / \mathrm{ha}$ and Vermicompost- $2.50 \mathrm{t} / \mathrm{ha}$ ) was found most effective as it gave highest flower size $(8.72 \mathrm{~cm})$, maximum oil percentage of flower $(0.44 \%)$ and highest C.B. ratio (1:4.10). Whereas application of $\mathrm{T}_{26}$ (Azotobacter- $500 \mathrm{ml} / \mathrm{ha}$, PSB- $1000 \mathrm{ml} / \mathrm{ha}$ and Vermicompost- $5.00 \mathrm{t} / \mathrm{ha}$ ) produced maximum ratio of disk and ray florets (1:4.04) and vase life of cut flower (8.80 days). Treatment $\mathrm{T}_{25}$ showed maximum length of flower stalk $(8.68 \mathrm{~cm})$, Number of ray florets $(192.20)$ were recorded under $T_{34}$ (Azotobacter- $750 \mathrm{ml} / \mathrm{ha}$, PSB- $1000 \mathrm{ml} / \mathrm{ha}$ and Vermicompost- $2.50 \mathrm{t} / \mathrm{ha}$ ) but number of disk florets were observed under $\mathrm{T}_{35}$ (Azotobacter- $750 \mathrm{ml} / \mathrm{ha}$, PSB- $1000 \mathrm{ml} / \mathrm{ha}$ and Vermicompost- $5.00 \mathrm{t} / \mathrm{ha}$ ).

\section{Introduction}

Marigold is one of the most important commercial flower crops grown all over the world and in India as well; accounting for more than half of Nation's loose flower production. It is native of central and South America especially Mexico and belongs to the family Asteraceae (Compositae). There are 33 species of genus tagetes in which few are important viz., Tagetes erecta, T. patula ,T. tenuifolia, T. luicida (sweet scented marigold), T. sarmetosa (climbing marigold), T. lacera, T. lemmmoni, T. minuta, T. filifolia (Irish lace). There are two species, which are commercially grown viz. Tagetes erecta L. 
(African marigold) and Tagetes patula L. (French marigold). This flower is extensively used for decoration in various religious and social functions, beautification of garden and for other commercial purposes likes extraction of perfume. In Mexico and Latin America, marigold flowers are used to decorate household alters to celebrate all saint and souls day (De and Bhattacharjee, 2011). Marigold is known as different name in different region e.g. friendship flower in United state, student enablement (student flower) in Germany, dead flower in Latin America and shayapatri in Nepal.

Its popularity, wide availability and multifarious uses, in no way is comparable with other flowers. It has a short duration to produce marketable flowers with wide spectrum of attractive colours, shape, size and good keeping quality, hence, attracted the attention of flower growers. It is use as cutflower for vase decoration and other arrangement besides loose flower for making garlands, decoration of buildings, gates, pandals during social functions, marriage ceremonies, worshipping and for floral rangoli. As garden plants for bedding and pot culture, herbaceous border, hanging baskets and window boxes, marigold is commonly grown in every home garden, parks and garden throughout the country. The uses of marigold are many fold, often referred to as, "Versatile crop with golden harvest". Marigolds produce thiopenes, which are toxic to nematodes and used as trap crop in tomato, brinjal, tobacco etc. (Raghava, 2000). It is not only cultivated as ornamental cut flower and landscape plant but also a source of carotenoid pigment for poultry feed to intensify yellow colour of egg yolks and broiler skin. Apart from poultry industry, marigold dye is also used in textile, pharmaceutical industries, food supplements, cosmetics etc as they offer several advantages over synthetic dyes from natural point of view, safety and eco-friendly in nature (Naik et al., 2004).

Due to raising cost of chemical fertilizers and problems of environmental pollution it has become imperative to arrive at an integrated nutrient management practices for marigold to achieve quality flowers at economical use of plant nutrients. Hence, an attempt is made to reduce the amount of nitrogenous and phosphatic fertilizers by substituting with biofertilizer and organic manure. This crop is a heavy feeder of nutrients, at present the nutrients are supplied through chemical fertilizers. Indiscriminate and continuous use of chemical fertilizer in intensive cropping system has led to an imbalance of nutrients in soil which has an adverse effect on soil health and also affecting flower quality.

Commercial exploitation of the flowers for xanthophylls extraction has made this flower crop much more popular among the flower growers and industries. In view of the above facts, the present study entitled, "Effect of integrated nutrient management with PGR on flower quality and economics of African marigold (Tagetes erecta L.) cv. Pusa Narangi Gainda" was undertaken.

\section{Materials and Methods}

An investigation was carried out during winter season of the year 2016-2017 and 2017-18 at Horticulture Research Farm, Department of Horticulture, Kulbhaskar Ashram P.G. College, Prayagraj (U.P.). The experiment was laid out in Randomized Block Design with three replications and 36 treatments with control. Under treatments as biofertilizers four levels of Azotobacter $(0,250,500$ and $750 \mathrm{ml} / \mathrm{ha})$ and three levels of PSB $(0,500$ and $1000 \mathrm{ml} / \mathrm{ha})$ was given as seedling treatment and three levels of Vermicompost $(0,2.5,5.0 \mathrm{t} / \mathrm{ha})$ will also be supplemented as organic manures during field 
preparation in selected plots. Cycocel @ 400 ppm was given as foliar feeding at 30 day after transplanting of seedling in each treatment except control as plant growth retardants.

The treatments detail is as follows, $\mathrm{T}_{0}$ (control), $\mathrm{T}_{1}$ (Vermicompost- $2.50 \mathrm{t} / \mathrm{ha}$ ), $\mathrm{T}_{2}$ (Vermicompost- 5.00 t/ha), $\mathrm{T}_{3}$ (PSB- 500 $\mathrm{ml} / \mathrm{ha}$ ), $\mathrm{T}_{4}$ (PSB- $500 \mathrm{ml} / \mathrm{ha}+$ Vermicompost$2.50 \mathrm{t} / \mathrm{ha}), \quad \mathrm{T}_{5} \quad(\mathrm{PSB}-500 \mathrm{ml} / \mathrm{ha}+$ Vermicompost- $5.00 \mathrm{t} / \mathrm{ha}$ ), $\mathrm{T}_{6}$ (PSB- 1000 $\mathrm{ml} / \mathrm{ha}$ ), $\quad \mathrm{T}_{7}$ (PSB- $1000 \mathrm{ml} / \mathrm{ha}+$ Vermicompost- $2.50 \mathrm{t} / \mathrm{ha}$ ), $\mathrm{T}_{8}$ (PSB- 1000 $\mathrm{ml} / \mathrm{ha}+$ Vermicompost- 5.00 t/ha), $\mathrm{T}_{9}$ (Azotobacter- $250 \mathrm{ml} / \mathrm{ha}$ ), $\mathrm{T}_{10}$ (Azotobacter$250 \mathrm{ml} / \mathrm{ha}+$ Vermicompost- $2.50 \mathrm{t} / \mathrm{ha}), \mathrm{T}_{11}$ (Azotobacter- $250 \mathrm{ml} / \mathrm{ha}+$ Vermicompost$5.00 \mathrm{t} / \mathrm{ha}$ ), $\mathrm{T}_{12}$ (Azotobacter- $250 \mathrm{ml} / \mathrm{ha}+$ PSB- $500 \mathrm{ml} / \mathrm{ha}$ ), $\mathrm{T}_{13}$ (Azotobacter- $250 \mathrm{ml} / \mathrm{ha}$ + PSB- $500 \mathrm{ml} / \mathrm{ha}+$ Vermicompost- 2.50 t/ha), $\mathrm{T}_{14}$ (Azotobacter- $250 \mathrm{ml} / \mathrm{ha}+$ PSB$500 \mathrm{ml} / \mathrm{ha}+$ Vermicompost- $5.00 \mathrm{t} / \mathrm{ha}), \mathrm{T}_{15}$ (Azotobacter- $250 \mathrm{ml} / \mathrm{ha}+$ PSB- $1000 \mathrm{ml} / \mathrm{ha}$ ), $\mathrm{T}_{16}$ (Azotobacter- $250 \mathrm{ml} / \mathrm{ha}+$ PSB- 1000 $\mathrm{ml} / \mathrm{ha}+$ Vermicompost- $2.50 \mathrm{t} / \mathrm{ha}), \mathrm{T}_{17}$ (Azotobacter- $250 \mathrm{ml} / \mathrm{ha}+\mathrm{PSB}-1000 \mathrm{ml} / \mathrm{ha}$ + Vermicompost- 5.00 t/ha), $\quad \mathrm{T}_{18}$ (Azotobacter- $500 \mathrm{ml} / \mathrm{ha}$ ), $\mathrm{T}_{19}$ (Azotobacter$500 \mathrm{ml} / \mathrm{ha}+$ Vermicompost- $2.50 \mathrm{t} / \mathrm{ha}), \mathrm{T}_{20}$ (Azotobacter- $500 \mathrm{ml} / \mathrm{ha}+$ Vermicompost$5.00 \mathrm{t} / \mathrm{ha}$ ), $\mathrm{T}_{21}$ (Azotobacter- $500 \mathrm{ml} / \mathrm{ha}+$ PSB- $500 \mathrm{ml} / \mathrm{ha}$ ), $\mathrm{T}_{22}$ (Azotobacter- $500 \mathrm{ml} / \mathrm{ha}$ + PSB- $500 \mathrm{ml} / \mathrm{ha}+$ Vermicompost- 2.50 t/ha), $\mathrm{T}_{23}$ (Azotobacter- $500 \mathrm{ml} / \mathrm{ha}+$ PSB$500 \mathrm{ml} / \mathrm{ha}+$ Vermicompost- $5.00 \mathrm{t} / \mathrm{ha}), \mathrm{T}_{24}$ (Azotobacter- $500 \mathrm{ml} / \mathrm{ha}+$ PSB- $1000 \mathrm{ml} / \mathrm{ha}$ ), $\mathrm{T}_{25}$ (Azotobacter- $500 \mathrm{ml} / \mathrm{ha}+$ PSB- 1000 $\mathrm{ml} / \mathrm{ha}+$ Vermicompost- $2.50 \mathrm{t} / \mathrm{ha}), \mathrm{T}_{26}$ (Azotobacter- $500 \mathrm{ml} / \mathrm{ha}+$ PSB- $1000 \mathrm{ml} / \mathrm{ha}$ + Vermicompost- 5.00 t/ha), $\quad \mathrm{T}_{27}$ (Azotobacter- $750 \mathrm{ml} / \mathrm{ha}), \mathrm{T}_{28}$ (Azotobacter$750 \mathrm{ml} / \mathrm{ha}+$ Vermicompost- $2.50 \mathrm{t} / \mathrm{ha}), \mathrm{T}_{29}$ (Azotobacter- $750 \mathrm{ml} / \mathrm{ha}+$ Vermicompost$5.00 \mathrm{t} / \mathrm{ha}$ ), $\mathrm{T}_{30}$ (Azotobacter- $750 \mathrm{ml} / \mathrm{ha}+$ PSB- $500 \mathrm{ml} / \mathrm{ha}$ ), $\mathrm{T}_{31}$ (Azotobacter- $750 \mathrm{ml} / \mathrm{ha}$
+ PSB- $500 \mathrm{ml} / \mathrm{ha}+$ Vermicompost- 2.50 $\mathrm{t} / \mathrm{ha}$ ), $\mathrm{T}_{32}$ (Azotobacter- $750 \mathrm{ml} / \mathrm{ha}+\mathrm{PSB}-500$ $\mathrm{ml} / \mathrm{ha}+$ Vermicompost- $5.00 \mathrm{t} / \mathrm{ha}), \mathrm{T}_{33}$ (Azotobacter- $750 \mathrm{ml} / \mathrm{ha}+\mathrm{PSB}-1000 \mathrm{ml} / \mathrm{ha}$ ), $\mathrm{T}_{34}$ (Azotobacter- $750 \mathrm{ml} / \mathrm{ha}+$ PSB- 1000 $\mathrm{ml} / \mathrm{ha}+$ Vermicompost- $5.00 \mathrm{t} / \mathrm{ha}$ ) and $\mathrm{T}_{35}$ (Azotobacter- $750 \mathrm{ml} / \mathrm{ha}+\mathrm{PSB}-1000 \mathrm{ml} / \mathrm{ha}+$ Vermicompost- 5.00 t/ha).

Flower characters viz., Size of flower, Length of flower stalk $(\mathrm{cm})$, Number of ray florets, Number of disk florets, Vase life of cut flower, Oil percentage, Ratio of Disk and Ray florets and C.B. ratio were recorded from five plants which were randomly selected and labelled in each plot of treatment.

\section{Results and Discussion}

Data presented in Table 1 and graphically depicted in Fig. 1, on flowers quality characters, show significant responses to different treatments of biofertilizers and organic manure with plant growth retardant.

The maximum size of flower $(8.72 \mathrm{~cm})$ were noticed in $_{22}$ followed by $\mathrm{T}_{23}(8.49 \mathrm{~cm})$ and $\mathrm{T}_{31}(8.28 \mathrm{~cm})$ while, minimum flower size $(5.30 \mathrm{~cm})$ was found under control $(5.30 \mathrm{~cm})$. The positive effect of Azotobacter, PSB and Vermicompost on flower diameter has been reported in marigold by Pushkar and Rathore (2011), Kaushik et al., (2013) and Naidu et al., (2014).

As far as, effect of integrated use of biofertlizers and Vermicompost on flower stalk length is concerned, the integrated nutrient management resulted in improved flower quality. $\mathrm{T}_{25}$ resulted in highest length of flower stalk $(8.68 \mathrm{~cm})$ followed by $T_{32}$ $(8.56 \mathrm{~cm})$ and $T_{31}(8.47 \mathrm{~cm})$ whereas, lowest length of flower stalk $(6.16 \mathrm{~cm})$ was recorded with $\mathrm{T}_{0}$ (control) presented in Table 1 and Fig. 2. 
Table.1 Effect of different doses on flower quality and economics of African marigold

\begin{tabular}{|c|c|c|c|c|c|c|c|c|c|}
\hline $\begin{array}{c}\text { Treatment } \\
\text { Number }\end{array}$ & Notations & $\begin{array}{c}\text { Size of } \\
\text { flower } \\
\text { (cm) }\end{array}$ & $\begin{array}{l}\text { Length o } \\
\text { flower } \\
\text { stalk } \\
(\mathrm{cm}) \\
\end{array}$ & $\begin{array}{l}\text { Number } \\
\text { of ray } \\
\text { florets }\end{array}$ & $\begin{array}{l}\text { Number } \\
\text { of disk } \\
\text { florets }\end{array}$ & $\begin{array}{l}\text { Vase life } \\
\text { of cut } \\
\text { flower }\end{array}$ & $\begin{array}{c}\text { Oil } \\
\text { percentage }\end{array}$ & $\begin{array}{c}\text { Ratio of } \\
\text { Disk and } \\
\text { Ray } \\
\text { florets }\end{array}$ & $\begin{array}{l}\text { C.B. } \\
\text { ratio }\end{array}$ \\
\hline $\mathbf{T}_{\mathbf{0}}$ & $\mathrm{A}_{0} \mathrm{P}_{0} \mathrm{~V}_{0}$ & 5.30 & 6.16 & 98.30 & 42.30 & 6.25 & 0.26 & 1.51 & $1: 1.96$ \\
\hline $\mathbf{T}_{1}$ & $\mathrm{~A}_{0} \mathrm{P}_{0} \mathrm{~V}_{1}$ & 6.22 & 7.38 & 118.10 & 61.10 & 6.90 & 0.33 & 1.92 & $1: 2.17$ \\
\hline $\mathbf{T}_{2}$ & $\mathrm{~A}_{0} \mathrm{P}_{0} \mathrm{~V}_{2}$ & 7.23 & 7.23 & 135.70 & 51.30 & 6.65 & 0.27 & 2.13 & $1: 2.08$ \\
\hline $\mathbf{T}_{3}$ & $\mathrm{~A}_{0} \mathrm{P}_{1} \mathrm{~V}_{0}$ & 5.37 & 6.83 & 119.80 & 55.60 & 6.40 & 0.31 & 1.74 & $1: 2.85$ \\
\hline $\mathbf{T}_{4}$ & $\mathrm{~A}_{0} \mathrm{P}_{1} \mathrm{~V}_{1}$ & 6.73 & 7.88 & 132.80 & 60.60 & 7.60 & 0.34 & 2.04 & $1: 2.95$ \\
\hline $\mathbf{T}_{5}$ & $\mathrm{~A}_{0} \mathrm{P}_{1} \mathrm{~V}_{2}$ & 7.39 & 7.94 & 159.20 & 63.20 & 7.05 & 0.36 & 2.49 & $1: 2.56$ \\
\hline $\mathbf{T}_{6}$ & $\mathrm{~A}_{0} \mathrm{P}_{2} \mathrm{~V}_{0}$ & 6.74 & 6.94 & 133.20 & 52.40 & 7.10 & 0.30 & 2.51 & $1: 2.54$ \\
\hline $\mathbf{T}_{7}$ & $\mathrm{~A}_{0} \mathrm{P}_{2} \mathrm{~V}_{1}$ & 6.48 & 7.81 & 151.70 & 64.90 & 6.90 & 0.35 & 2.47 & $1: 2.75$ \\
\hline $\mathbf{T}_{8}$ & $\mathrm{~A}_{0} \mathrm{P}_{2} \mathrm{~V}_{2}$ & 7.38 & 7.94 & 139.10 & 63.40 & 7.90 & 0.32 & 2.71 & $1: 2.50$ \\
\hline $\mathbf{T}_{9}$ & $\mathrm{~A}_{1} \mathrm{P}_{0} \mathrm{~V}_{0}$ & 7.34 & 6.26 & 140.10 & 54.50 & 6.60 & 0.27 & 2.08 & $1: 2.55$ \\
\hline$T_{10}$ & $\mathrm{~A}_{1} \mathrm{P}_{0} \mathrm{~V}_{1}$ & 7.21 & 7.61 & 141.60 & 44.90 & 7.35 & 0.32 & 2.67 & $1: 2.80$ \\
\hline$T_{11}$ & $\mathrm{~A}_{1} \mathrm{P}_{0} \mathrm{~V}_{2}$ & 7.41 & 7.95 & 127.90 & 55.20 & 6.95 & 0.32 & 2.06 & $1: 2.23$ \\
\hline$T_{12}$ & $A_{1} P_{1} V_{0}$ & 6.69 & 7.37 & 173.30 & 60.60 & 6.65 & 0.28 & 3.32 & $1: 3.02$ \\
\hline$T_{13}$ & $\mathrm{~A}_{1} \mathrm{P}_{1} \mathrm{~V}_{1}$ & 7.84 & 7.06 & 160.90 & 61.50 & 7.25 & 0.38 & 2.7 & $1: 3.25$ \\
\hline$T_{14}$ & $A_{1} P_{1} V_{2}$ & 5.88 & 6.71 & 139.90 & 57.80 & 7.15 & 0.30 & 2.71 & $1: 3.20$ \\
\hline$T_{15}$ & $A_{1} P_{2} V_{0}$ & 6.71 & 6.85 & 137.60 & 53.00 & 6.90 & 0.30 & 2.37 & $1: 3.19$ \\
\hline$T_{16}$ & $A_{1} P_{2} V_{1}$ & 7.38 & 7.99 & 154.20 & 45.90 & 7.85 & 0.31 & 3.0 & $1: 3.38$ \\
\hline$T_{17}$ & $A_{1} P_{2} V_{2}$ & 6.96 & 8.26 & 149.90 & 58.70 & 7.95 & 0.41 & 2.94 & $1: 3.58$ \\
\hline$T_{18}$ & $\mathrm{~A}_{2} \mathrm{P}_{0} \mathrm{~V}_{0}$ & 8.08 & 7.42 & 147.00 & 50.40 & 7.55 & 0.32 & 2.41 & 1:3.16 \\
\hline$T_{19}$ & $\mathrm{~A}_{2} \mathrm{P}_{0} \mathrm{~V}_{1}$ & 6.18 & 7.69 & 160.50 & 51.60 & 7.00 & 0.36 & 2.83 & 1:3.01 \\
\hline$T_{20}$ & $\mathrm{~A}_{2} \mathrm{P}_{0} \mathrm{~V}_{2}$ & 6.39 & 7.93 & 142.60 & 53.10 & 7.05 & 0.36 & 2.49 & $1: 3.24$ \\
\hline$T_{21}$ & $A_{2} P_{1} V_{0}$ & 7.25 & 16 & 8.20 & 65.60 & 6.30 & 0.30 & 3.02 & 1:3.66 \\
\hline$T_{22}$ & $A_{2} P_{1} V_{1}$ & 8.72 & 8.40 & 178.90 & 2.80 & 85 & 0.44 & 3.89 & 1:4.10 \\
\hline$T_{23}$ & $A_{2} P_{1} V_{2}$ & 8.49 & 8.32 & 163.20 & 4.85 & 50 & 0.42 & 3.28 & $1: 3.58$ \\
\hline $\mathbf{T}_{24}$ & $A_{2} P_{2} V_{0}$ & 7.75 & 6.99 & 9.60 & 3.70 & 90 & 0.41 & 2.58 & $1: 3.63$ \\
\hline$T_{25}$ & $\mathrm{~A}_{2} \mathrm{P}_{2} \mathrm{~V}_{1}$ & 8.13 & 8.68 & 8.80 & 5.80 & 25 & 0.34 & 3.61 & $1: 3.32$ \\
\hline$T_{26}$ & $A_{2} P_{2} V_{2}$ & 6.73 & 8.11 & 3.40 & 8.20 & 80 & 0.32 & 4.04 & $1: 3.15$ \\
\hline$T_{27}$ & $\mathrm{~A}_{3} \mathrm{P}_{0} \mathrm{~V}_{0}$ & 7.22 & 7.97 & 9.90 & 2.90 & 7.15 & 0.28 & 2. & $1: 3.04$ \\
\hline$T_{28}$ & $\mathrm{~A}_{3} \mathrm{P}_{0} \mathrm{~V}_{1}$ & 6.66 & 99 & & 0.60 & 65 & 0.33 & 3. & :2.86 \\
\hline$T_{29}$ & $A_{3} P_{0} V_{2}$ & 7.48 & 04 & 8.70 & .20 & 40 & 0.35 & 2. & :3.29 \\
\hline $\mathbf{T}_{30}$ & $\mathrm{~A}_{3} \mathrm{P}_{1} \mathrm{~V}_{0}$ & 7.25 & 7.88 & 173.30 & 6.20 & 35 & 0.39 & 3.02 & $1: 3.59$ \\
\hline $\mathbf{T}_{31}$ & $\mathrm{~A}_{3} \mathrm{P}_{1} \mathrm{~V}_{1}$ & 8.28 & 8.47 & 175.70 & .45 & 45 & 0.42 & 3. & $1: 3.71$ \\
\hline$T_{32}$ & $A_{3} P_{1} V_{2}$ & 7.15 & 8.56 & 149.50 & 52.60 & 6.85 & 0.39 & 3.16 & $1: 3.29$ \\
\hline$T_{33}$ & $A_{3} P_{2} V_{0}$ & 8.06 & 8.22 & 156.80 & 52.50 & 6.45 & 0.36 & 2.86 & $1: 3.65$ \\
\hline$T_{34}$ & $A_{3} P_{2} V_{1}$ & 7.11 & 7.56 & 192.20 & 52.40 & 7.55 & 0.42 & 3.92 & $1: 3.74$ \\
\hline $\mathbf{T}_{35}$ & $A_{3} P_{2} V_{2}$ & 8.11 & 8.31 & 190.00 & 53.90 & 8.05 & 0.43 & 3.18 & $1: 3.70$ \\
\hline SE(d) & & 0.22 & 0.28 & 3.46 & 1.73 & 0.22 & 0.03 & 0.14 & 0.14 \\
\hline C.D. at $5 \%$ & & 0.43 & 0.55 & 6.82 & 3.41 & 0.44 & 0.05 & 0.28 & 0.27 \\
\hline
\end{tabular}



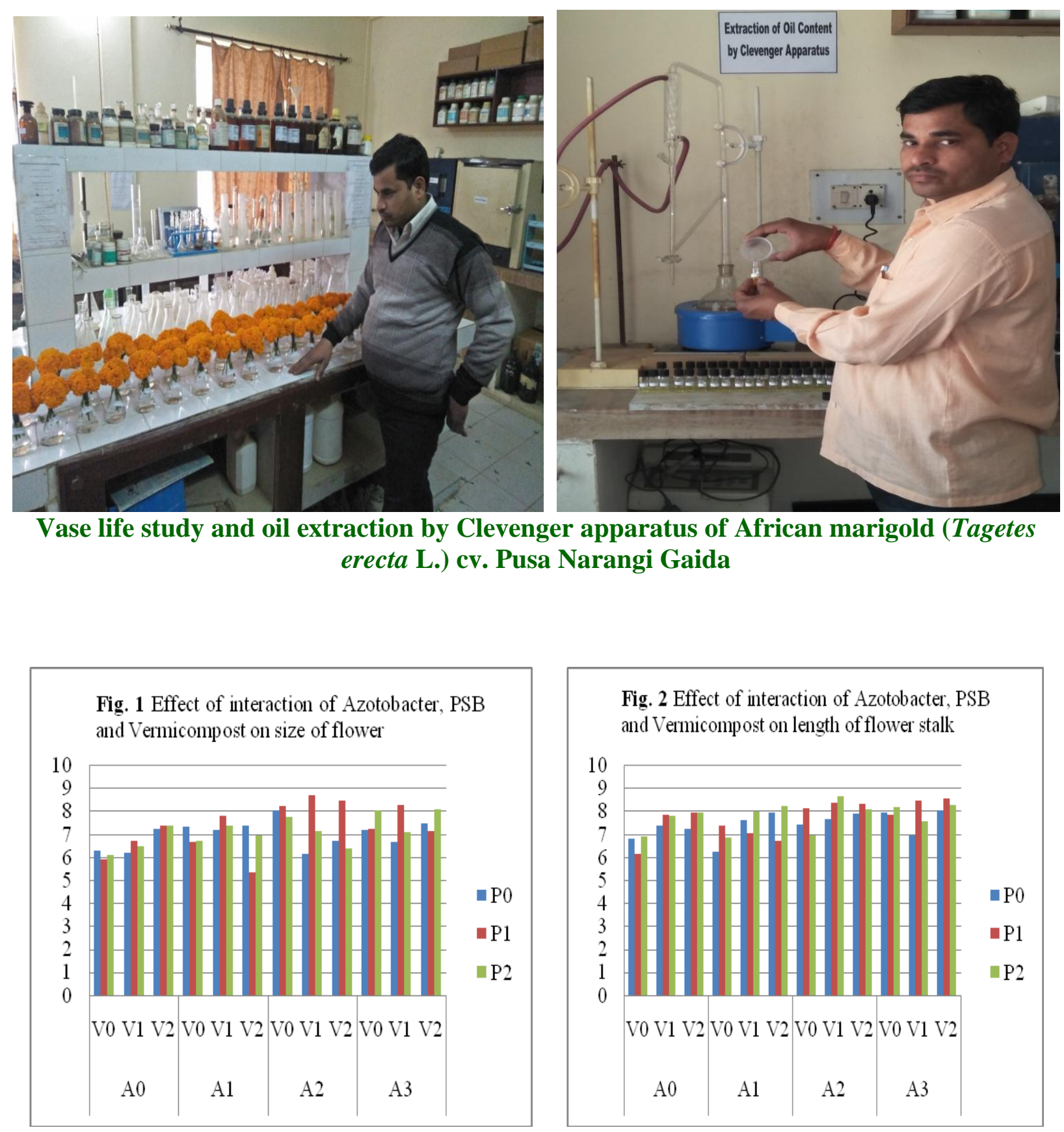

\section{Vase life study and oil extraction by Clevenger apparatus of African marigold (Tagetes erecta L.) cv. Pusa Narangi Gaida}

Fig. 1 Effect of interaction of Azotobacter, PSB and Vermicompost on size of flowe
Fig. 2 Effect of interaction of Azotobacter, PSB and Vermicompost on length of flower stalk

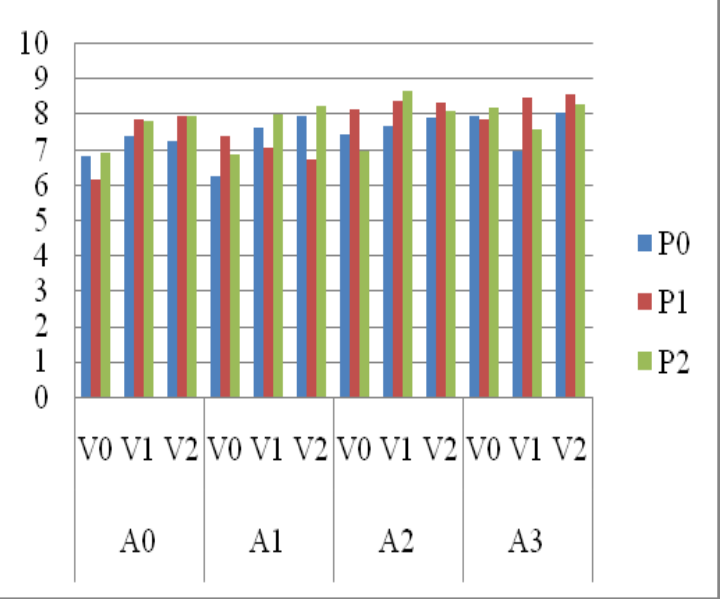



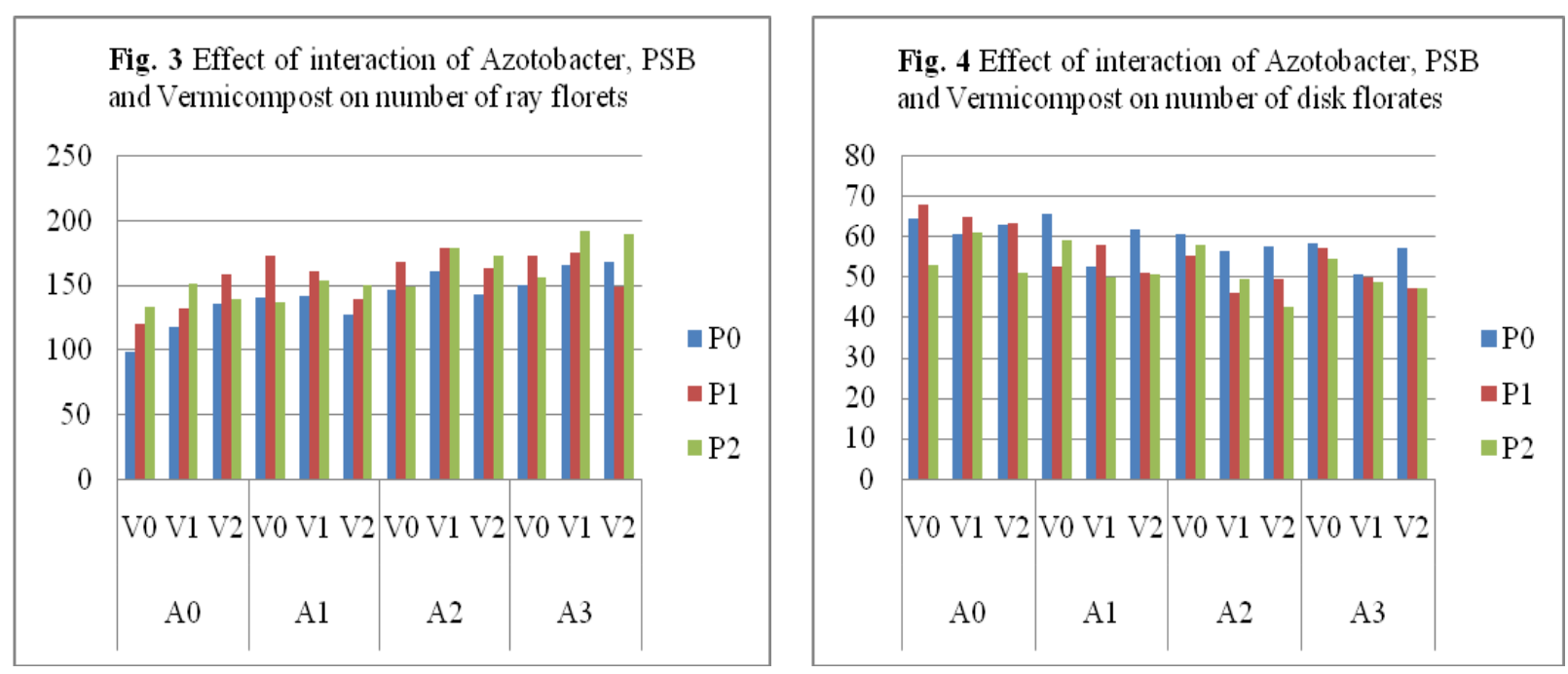

Fig. 5 Effect of interaction of Azotobacter, PSB and Vermicompost on vase life of flower

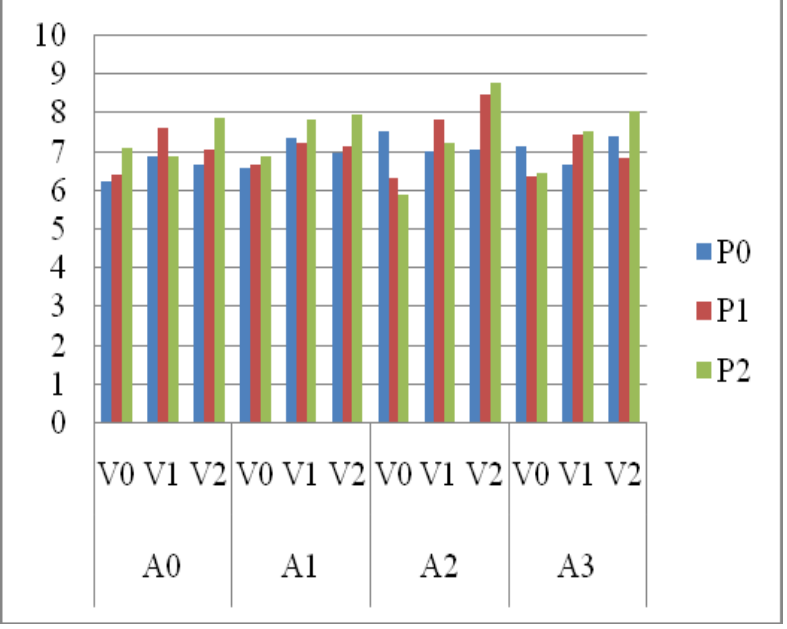

Fig. 6 Effect of interaction of Azotobacter and PSB on oil percent
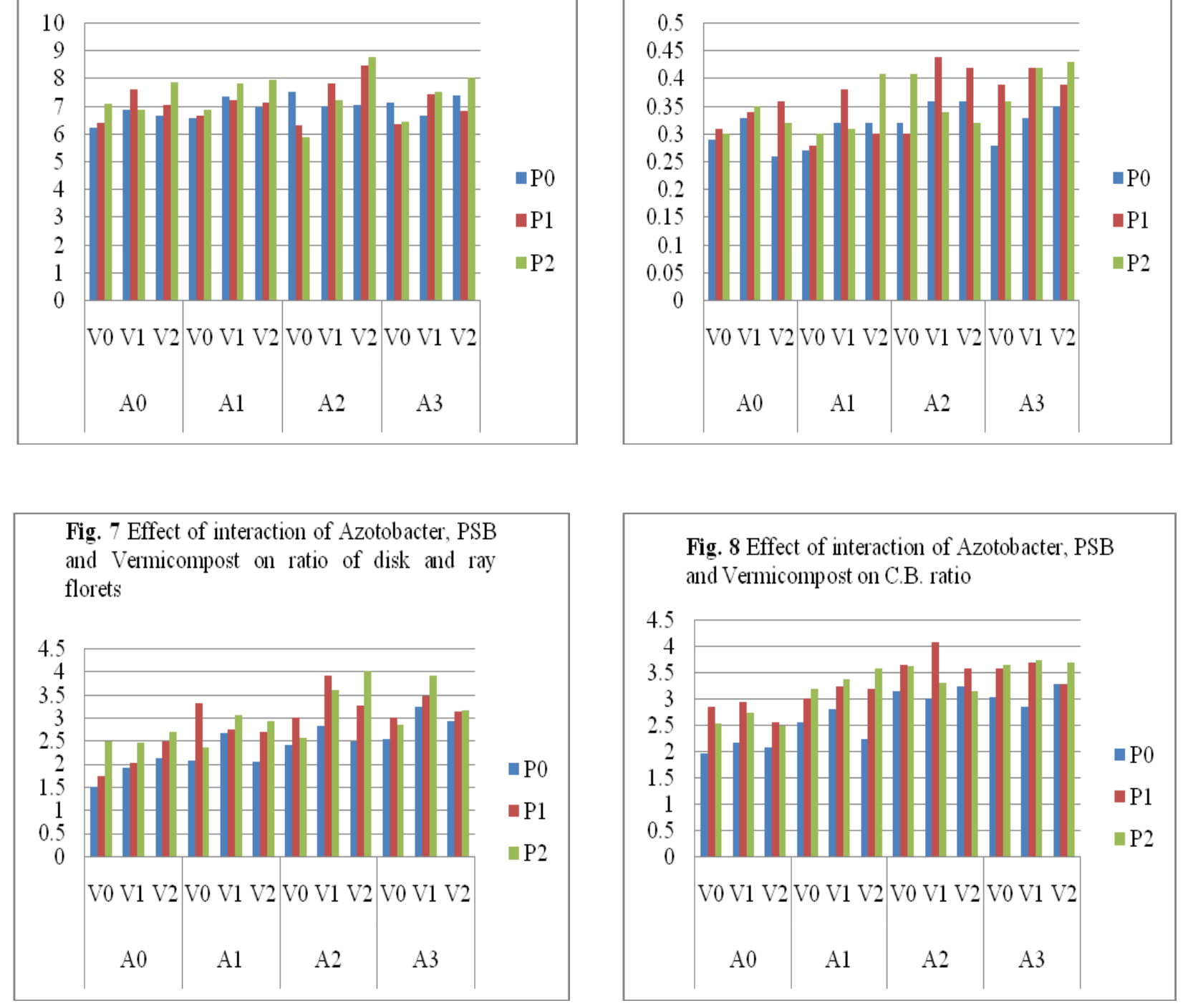
The results showed in Table 1 and Fig. 3 that maximum number of ray florets (192.20) was recorded in $\mathrm{T}_{34}$ followed by $\mathrm{T}_{35}$ (190.00) and $\mathrm{T}_{22}$ (178.90) whereas, control plants produced with minimum number of ray florets (98.30). Similar, reports were made by Das and Mishra (2005), Kaushik et al., (2013) and Kumar et al., (2017) and maximum number of disk florets per flower (68.20) was reported with $\mathrm{T}_{26}$ followed by $\mathrm{T}_{21}(65.60)$ and $\mathrm{T}_{7}$ (64.90) while, number of minimum disk florets per flower (42.30) was noticed under $\mathrm{T}_{0}$ (control) presented in Table 1 and Fig. 4.

Pooled data of both the years reveals that the maximum vase life of flowers was observed under $\mathrm{T}_{26}$ ( 8.80 days) followed by $\mathrm{T}_{23}(8.50$ days) and $T_{35}$ (8.05 days) showed in Table 1 and Fig.5. This findings was in agreement with the findings of Joshi and Barad (2002), Yadav et al., (2018), Goutham Kishore et al., (2018) in Marigold, Nethra et al., (1999), Parmar (2007), Kumar et al., (2016), Sharma et al., (2017), Sathyanarayana et al., (2017) in China aster and Pandey et al., (2018) in chrysanthemum. While minimum keeping quality was observed with $\mathrm{T}_{24}$ (5.90 days).

The data presented in Table 1 and Fig. 6 clearly indicate that the significantly highest oil percentage of flower $(0.44 \%)$ was reported with $\mathrm{T}_{22}$ followed by $\mathrm{T}_{35}(0.43 \%), \mathrm{T}_{34}(0.42)$ and $\mathrm{T}_{23}(0.42 \%)$ whereas, lowest oil content in flower $(0.26 \%)$ was weighted under $\mathrm{T}_{1}$ (control). These findings confirmed those reported by Kazemi et al., (2014), Girwani et al., (1990).

The combined application of bio-fertilizers and organic manures significantly increased ratio of disk and ray florets (4.04) under treatment $\mathrm{T}_{26}$, followed by treatment $\mathrm{T}_{34}$ (3.92), $\mathrm{T}_{22}$ (3.89) and $\mathrm{T}_{25}$ (3.61). While minimum ratio of disk and ray florets (1.51) was observed under control, which is presented in Table 1 and Fig. 7.
Thus, the results have proved that application of $\mathrm{T}_{22}\left(\mathrm{~A}_{2} \mathrm{P}_{1} \mathrm{~V}_{1}\right)$ is most effective (1:4.10) in enhancing C.B. ratio of African marigold (Tagetes erecta $\mathrm{L}$.) followed by $\mathrm{T}_{34}(1: 3.74)$, $\mathrm{T}_{31}$ (1:3.71) and $\mathrm{T}_{35}(1: 3.70)$ due to increase in number of flowers bearing branches, number of flower per plant, Average weight of flower and size of flower presented in Table 1 and Fig. 8. These results are also similar with Verma et al., (2011) in marigold, Meshram et al., (2008) in chrysanthemum and Deshmukh et al., (2008) in Gaillardia.

\section{References}

Das, J. N. and Mishra, H. N. 2005. Studied on graded dose of fertilizers and polythene mulch on growth. Flowering and yield of African gold (Tagetes erecta L.) cv. Siracole. Orissa journal of Horticulutre, 33 (2): 42-45.

De, L. C. and Bhattacharjee, S. K. 2011. 'Ornamental Crop Breeding'.Pp. 438, Published by Aaivishkar Publishers \& Distributors, Jaipur, Rajasthan.

Deshmukh, P. G., Khiratkar, S. D., Badge, S. A. and Bhongle, S. A. 2008. Effect of bioinoculants with graded doses of NPK on growth and yield of gaillardia. Journal of Soils and Crops, 18(1):212-216.

Girwani, A., Srihari, R. B. and Chandrasekhar, R. 1990. Response of marigold (Tagetes erecta L.) to growth regulators and zinc. Indian journal of Agricultural sciences, 60(3): 220-222.

Goutham Kishore B. K., Punetha P. and Bohra M. 2018. Efficacy of Azotobacter and Phosphate Solubilizing Bacteria on vegetative and floral attributes of African marigold (Tagetes erecta L.) cv. Pusa Narangi Gainda under Hilly Regions of Uttarakhand. International Journal of Agriculture Sciences, 10(4): 5212-5215.

Joshi, N. S. and Barad, A. V. 2002. Effect of N, P and pinching on growth, yield and quality of African marigold (Tagetes erecta L.) cv. Crackerjack. Gujarat J. Applied Hort., 1(1): 57-65.

Kaushik, H., Singh, J. P., Brajmohan, R. and 
Nathiram 2013. Effect of inorganic fertilizer (nitrogen) and bio-fertilizer (Azospirillum) on growth and flowering in African marigold (Tagets erecta L.) cv. Pusa Narangi Gainda. International Journal of Agricultural Sciences, 9(1):189-192.

Kazemi, S. S., Hashemabadi, D., Torkashvand, A. M. and Kaviani, B. 2014. Effect of cycocel and daminozide on vegetative growth, flowering and the content of essence of pot marigold (Calendula officinalis). Journal of Ornamental Plants, 4(2): 107-114. 10

Kumar, A. and Kumar, A. 2017. Effect of biofertilizers and nutrients on growth and flower yield of summer season African marigold (Tagetes erecta L.). Plant Archives, 17(2): 1090-1092.

Kumar, P., Kumar, V. and Kumar, D. 2016. Response of INM to Plant growth, Flower yield and Shelf life of African marigold (Tagetes erecta L.) cv. Pusa Basanti Gainda. International Journal of Agricultural Invention, 1(1): 108 - 112.

Meshram, N., Badge, S., Bhongle, S. A. and Khiratkar, S. D. 2008. Effect of bioinoculants with graded doses of NPK on flowering, yield attributes and economics of annual chrysanthemum. J. Soils and Crops, 18(1): 217-220.

Naidu, J. H., Ashok, P., Chandrasekhar, R. and Sasikala, K. 2014. Effect of plant growth retardants and spacing's on vegetative growth and flower yield of African marigold (Tagetes erecta L) cv. Pusa Narangi Gainda. International Journal of Farm Sciences 4(2): 92-99.

Naik, H. B., Patil, A. A., Patil, V. S., Basavaraj, N. and Heremath, S. M. 2004. Effect of pinching and chemicals on xanthophylls yield in African marigold (Tagetes erecta L.). J. Ornamental Horticulture, 7(3-4): 182-190.

Nethra, N. N., Jayaprasad, K. V. and Kale, R. D. 1999. China aster (Callistephus chinensis L. Nees.) cultivation using vermicompost as organic amendment. Crop Res., 17(2): 209-215.

Pandey, G., Kumar, R., Kumar, S. and Kumar, A. 2018. Effect of integrated nutrient management on floral parameters and soil nutrient status in chrysanthemum (Chrysanthemum morifolium Ramat.). International Journal of Current Microbiology and Applied Sciences, 7(5): 1984-1990.

Parmar, N. A. 2007. Response of biofertilizers and nitrogenous fertilizer on growth, flower yield and quality of China aster (Callistephus chinensis L. Nees.) under South Gujarat condition. M.Sc. (Agri.) Thesis, NAU, Navsari.

Pushkar, N. C. and Rathore, S. V. S. 2011. Effect of nutrients and bio-inoculants on growth, flowering behaviour and yield of African marigold (Tagetes erecta L.) var. Pusa Narangi Gainda. Progressive Horticulture, 43(2): 225-227.

Raghava, S. P. S. 2000. Marigold versatile crop with golden harvest. Floriculture Today, 4 (11): 40-41.

Sathyanarayana, E., Patil, S., Chawla, S. L. and Patel, D. K. 2017. Influence of integrated nutrient management on gladiolus (Gladiolus grandiflorus L.) cv. American Beauty. International Journal of Current Microbiology and Applied Sciences, 6(8): 379-386.

Sharma, A., Sharma, K., Gaur, D., Dhakad, H., Banafer, R. N. S. and Lekhi, R. 2017. Effect of integrated nutrient management on growth, flower yield and vase life of marigold cv. Pusa Narangi. Journal of Pharmacognosy and Phytochemistry, 6(6): 319-323.

Verma, S. K., Angadi, S. G., Patil, V. S., Mokashi, A. N., Mathad, J. C. and Mummigatti, U. V. 2011. Growth, yield and quality of chrysanthemum (Chrysanthemum morifolium Ramat.) cv. Raja, as influenced by integrated nutrient management. Karnataka J. Agric. Sci., 24 (5): 681-683.

Yadav, K. S., Pal, A.K., Singh, A. K., Yadav, D. and Maurya, S. K. 2018. Effect of different bio-fertilizers on growth and flowering of marigold. Journal of Pharmacognosy and Phytochemistry, 7(1): 1548-1550. 


\section{How to cite this article:}

Yatendra Kumar, Vishwanath and Upadhyay, P. K. 2020. Effect of Integrated Nutrients Management with Plant Growth Retardant on Flower Quality and Economics of African Marigold (Tagetes erecta L.) cv. Pusa Narangi Gainda. Int.J.Curr.Microbiol.App.Sci. 9(02): 1631-1639. doi: https://doi.org/10.20546/ijcmas.2020.902.187 